University of Michigan Law School University of Michigan Law School Scholarship Repository

1987

\title{
The American Advantage: The Value of Inefficient Litigation
}

Samuel R. Gross

University of Michigan Law School, srgross@umich.edu

Available at: https://repository.law.umich.edu/articles/197

Follow this and additional works at: https://repository.law.umich.edu/articles

Part of the Civil Procedure Commons, Comparative and Foreign Law Commons, $\underline{\text { Courts }}$ Commons, and the Litigation Commons

\section{Recommended Citation}

Gross, Samuel R. "The American Advantage: The Value of Inefficient Litigation." Mich. L. Rev. 85 (1987): 734-57.

This Article is brought to you for free and open access by the Faculty Scholarship at University of Michigan Law School Scholarship Repository. It has been accepted for inclusion in Articles by an authorized administrator of University of Michigan Law School Scholarship Repository. For more information, please contact mlaw.repository@umich.edu. 


\title{
THE AMERICAN ADVANTAGE: THE VALUE OF INEFFICIENT LITIGATION
}

\author{
Samuel R. Gross*
}

In a recent article, The German Advantage in Civil Procedure, ${ }^{1}$ Professor John Langbein claims that the German system of civil litigation is superior to the American; in an earlier article he makes a parallel claim about German criminal procedure. ${ }^{2}$ Roughly, Professor Langbein argues that by comparison to the German process, American litigation is overly complex, expensive, slow, and unpredictable in short, inefficient. ${ }^{3}$ Professor Langbein is not the first and will not be the last to criticize American legal institutions in these terms, but he expresses this criticism particularly well: he is concise and concrete, he describes American practice by reference to a specific and important foil, and he has a clear and articulate point of view. Professor Langbein is also quite convincing; some may disagree but I, for one, have no basis to dispute his claims, and no impulse to try. The point of this paper is different: to question the assumption that efficiency in adjudication is a virtue.

This seems, at first blush, an odd argument: not merely that efficiency is a goal that must at times be compromised to accommodate other goals, but rather that in some contexts efficiency (as commonly measured) may be incompatible with other values, and that for some purposes inefficiency may be desirable in itself. Perhaps this strange position deserves a more committed advocate. I advance a number of arguments against efficiency in litigation, but I am not entirely convinced by them; I only neglect the opposing arguments because they are more obvious and better stated by others. My point is more modest: that efficiency is a poor measure of the quality of a procedural system, one way or the other.

* Associate Professor of Law, University of Michigan. A.B. 1968, Columbia College; J.D. 1973, University of California at Berkeley. - Ed.

This article has benefited from research assistance by Yonkel Goldstein, and from comments by several colleagues who read an earlier draft: Robert Ellickson, Lawrence Friedman, and John Langbein, who suggested various changes; and Robert Weisberg, who did not.

1. Langbein, The German Advantage in Civil Procedure, 52 U. Chi. L. REv. 823 (1985).

2. Langbein, Land Without Plea Bargaining: How the Germans Do It, 78 MiCH. L. REv. 204 (1979).

3. Langbein also argues that German courts are more accurate than American courts. Conceptually, superior accuracy is a component of "efficiency" in a legal system, but on this item I find Professor Langbein's argument unpersuasive. See text at note 21 infra. 
The structure of this article is simple. I begin with a short (and perhaps somewhat idealized) description of the comparative advantages of the German system of litigation, drawing heavily on Langbein's work, and in that context explain what I mean when I say that the American system is inefficient. I then turn briefly to various defenses of our system, and distinguish them from the present line of argument. Last, and most important, I offer a number of reasons to doubt the value of efficiency in a legal system, and to favor inefficient procedures instead.

\section{AMERICAN INEFFICIENCY}

The comparative inefficiency of American civil litigation is best understood by focusing on what happens before trial. In this respect, the contrast with German procedure is stark: in America, almost everything happens before trial; in Germany, relatively little. ${ }^{4}$ This feature of German civil litigation is a direct result of the fact that investigation and presentation of evidence is a public function, dominated by judges, rather than a private function run by lawyers.

In a German civil case, the judge to whom the case is assigned initiates all major activities after the filing of the initial pleadings, and all subsequent proceedings are considered parts of the "trial."s Once the judge is reasonably familiar with the issues, he will summon the lawyers (and possibly the parties) to a conference, and attempt to resolve the dispute. If that is not possible, he will take evidence by calling those witnesses whose value is apparent from the outset of the dispute, or who are suggested by the parties. These witnesses are questioned primarily by the judge, although counsel may add questions at the end of the examinations. The witnesses are not prepared in advance by the court, or by counsel, and they do not generally all testify at a single hearing. There is no set order to a German trial - nothing similar to our own sequence of plaintiff's case-in-chief, defendant's case, plaintiff's rebuttal, etc. — but there is a set aim: to find a factual or a legal basis to resolve the case as quickly and easily as possible. If a particular witness or set of witnesses provides the basis for a judgment, so much the better; if not, another avenue must be explored which means another hearing and probably other witnesses.

By comparison to American practice, the biggest time-saving feature of German civil procedure is the absence of pretrial discovery. In Germany evidence is produced only once, in America it is produced

4. Langbein, supra note 1 , at $826-30$.

5. Id. at $827-29,837,839$. 
and reviewed redundantly. ${ }^{6}$ This difference is magnified by two essential features of American civil litigation: (1) Because the preparation is adversarial, there is a large duplication of effort between the two sides. (2) Because American trials are unitary events, with jury deliberations and judgment at the conclusion of all the evidence, the adversaries must prepare in advance for all possible contingencies. In Germany, by contrast, evidence is developed by only one person the judge - and only to the extent necessary to resolve the case. ${ }^{7}$

German civil procedure is less formal and elaborate than our own. A particularly important difference is the absence of the many traditional exclusionary rules of evidence that govern common-law trials. In addition, the testimony of German witnesses is not usually recorded and transcribed verbatim, as it is in America; rather, the judge dictates summaries of testimony, producing a more concise and usable record. ${ }^{8}$ On the other hand, the judgments of German courts are vastly more detailed than the enigmatic verdicts of common-law juries, specifying the factual findings and legal conclusions on which the court's action is based. These two last features of German civil procedure - concise records and detailed written judgments - make possible a process of appellate review that is both more economical and more wide ranging than American procedure permits. ${ }^{9}$

If the big difference between Germany and America in civil litigation is the absence of discovery, the big difference in criminal litigation is the absence of plea bargaining. A criminal prosecution in Germany, as in America, begins with an official investigation of an alleged crime, typically by the police, occasionally with some participation by the prosecutor. German investigations may be more formal and structured than the American, but on the whole this stage of the proceedings is reasonably similar. ${ }^{10}$ Once this initial investigation is complete, control of the case shifts to the prosecutor, and at that point similarity between the two systems ends. An American prosecutor has essen-

6. $I d$. at 831 .

7. This description is an ideal type. American civil procedure does provide some mechanisms for narrowing the range of issues before trial, e.g., the possibility of motions for partial summary judgment under FED. R. CIV. P. 56 and analogous state provisions. Langbein cites the phenomenon of "managerial judging," see Resnik, Managerial Judges, 96 HARV. L. REV. 374 (1982), as evidence of a shift in American litigation in the direction of continental practice. Langbein, supra note 1 , at 825 . There may be something to this, but any drift in that direction will be severely limited by major structural elements of the common-law system, in particular the institution of the jury trial. In any event, as things stand the two systems are far apart.

8. Langbein, supra note 1 , at 828-29.

9. Id. at 857. See generally Meador, Appellate Subject Matter Organization: The German Design from an American Perspective, 5 Hastings INTL. \& CoMP. L. ReV. 27 (1981).

10. J. Langbein, Comparative Criminal Procedure: Germany 11-13 (1977). 
tially absolute discretion to charge the apparent malefactor or to decline to do so, and to decide the nature of charges; once charges have been filed the prosecutor may request the court to dismiss or compromise them, and the request will usually be rubber-stamped. This prosecutorial power makes possible the ubiquitous American practice of plea bargaining, trading guilty pleas for charges and sentences less than the available maximum. By most estimates, ninety percent or more of criminal convictions in America are the product of plea bargains. ${ }^{11}$ In Germany, this practice is unknown and impossible. A German prosecutor has a duty to consider evidence on both sides and to make what amounts to a probable cause determination: is there sufficient evidence to prove that the defendant committed a crime? If the evidence satisfies this standard, the prosecutor has no discretion to decline to charge the defendant or to mitigate the charges, and once charges have been filed, the prosecutor has no power to dismiss or to compromise. ${ }^{12}$ As a result, all serious criminal cases in Germany proceed to trial, and all convictions are based on adjudications of guilt rather than pleas.

How can the Germans function entirely without the central element of American criminal procedure? The answer is that plea bargaining is necessary in America in order to avoid the process of criminal litigation, since it would be prohibitively expensive and time consuming to hold trials in any substantial fraction of criminal cases. In Germany, however, criminal trials are vastly quicker and cheaper. In many ways, German criminal trials resemble their civil trials: the examination of witnesses is nonadversarial, free from most of our exclusionary rules of evidence, and conducted primarily by the judge. But there are several important differences: (1) A major goal of a German judge in a civil case is to facilitate a private settlement. In a criminal case there is no such thing as a settlement; the primary functions of the court are to judge the question of guilt (by a standard similar to proof beyond a reasonable doubt), and, if guilt is found, to determine the penalty. ${ }^{13}$ (2) Examination at trial is based on a pretrial investigation by the police and the prosecution, which is compiled and presented to the court in a "dossier"; the defense has access to the dossier and can move for investigation of claims that have been overlooked. ${ }^{14}$ (3) Although there are no juries in German criminal cases,

11. See, e.g., D. Newman, Conviction: The Determination of Guilt oR InNocence WITHOUT TRIAL 3 (1966); PRESIDENT's COMMISSION ON LAW ENFORCEMENT AND ADMINIStration of Justice, The Challenge of Crime in a Free Society 134 (1967).

12. Langbein, supra note 2 , at 210-12.

13. Id. at 208; J. LANGBEIN, supra note 10, at 78-79.

14. J. LANGBEIN, supra note 10 , at $9,12-13,67-68,74-75$. 
criminal courts include lay judges who sit and vote together with professional judges. ${ }^{15}$ (4) Unlike civil trials, German criminal trials are generally concentrated affairs that start and end at a single sitting. ${ }^{16}$

Most German criminal trials begin with an examination of the accused. The accused is informed that he may remain silent, but few defendants exercise that right and many confess. Whether or not there is a confession, the court must satisfy itself that guilt has been proved; in either event, taking testimony initially from the defendant is likely to narrow the range of issues that are in dispute. ${ }^{17}$ That saving, together with the simplified presentation of evidence and the absence of most of the procedural issues that characterize American criminal trials, produces a streamlined proceeding: the average length of major criminal trials in Germany is one day, of lesser criminal trials onethird of a day. ${ }^{18}$ At the conclusion of the case, the court decides guilt and penalty simultaneously; as in civil cases, its judgment is embodied in an opinion written by a professional judge, including findings of fact and conclusions of law. Both sides have a liberal right to appeal the sentence as well as the verdict. ${ }^{19}$

In sum, German procedure, both civil and criminal, is more compact than its American counterpart. The duplication of effort that is inherent in adversarial fact-finding is largely eliminated. In civil cases, far less happens before trial; in all cases, the trials themselves are less bound by procedural rules. The examination of witnesses is much quicker - one questioner is likely to consume less than half the time of two - and it focuses more effectively on the critical issues at stake. Trial records are more concise, but legal judgments are more elaborate and reasoned, and subject to more extensive review.

Accepting this description of the German legal system as accurate, in what sense is it more efficient than ours? Some parts of the answer to this question are obvious, but others perhaps less so.

Efficiency is a measure of the relationship of a value or benefit to the cost of producing it; the higher the value per cost, the higher the efficiency. ${ }^{20}$ This seems simple enough - definitions often do - until

15. Id. at 61-63; Langbein, supra note 2, at 206.

16. J. LANGBEIN, supra note 10, at 68.

17. Id. at 73-74.

18. Id. at 77.

19. Id. at 83-85.

20. Strictly speaking, economists define efficiency in terms of "Pareto superiority": a condition is said to be "Pareto superior" to an alternative condition (i.e., more "efficient") if and only if at least one person is better off and no person is worse off. This is a highly restrictive definition. Using this as a standard, it is impossible to say that a change that provides a $\$ 100$ benefit to a poor person at the cost of taking $\$ 1$ from a rich person improves the efficiency of an economic system. See Economic Foundations of Property LaW xi-xiv (B. Ackerman ed. 1975). In 
we try to define the component parts: benefit and cost. This can be tricky even when the issue is a relatively direct economic calculation - for example, the efficiency of a productive enterprise. In particular, the ratio of benefits to costs may depend critically on the valuation of unknown risks and other imponderables, and on the time frame within which one chooses to calculate. But here the question is a far more complex one - the efficiency of a major portion of the legal system, a basic function of government. In a context such as this, the notion of efficiency can be used in a sense that is so broad that it loses any analytic value. It is reasonable to consider the efficiency of a legal system as a function of its net social utility, but it is uninteresting. For example, if one defines an efficient legal system as one that, in the long run, promotes the greatest social good, then the social value of efficiency becomes tautologically undeniable, and the descriptive power of the concept evaporates: to describe what is good as "efficient" does not help us to recognize the good. For present purposes, I will stick to a more restrictive definition, and discuss the efficiency of legal procedures in terms of more direct costs and benefits.

The most obvious basis for the assertion that German litigation is more efficient than American litigation is the claim that it is cheaper. It simply costs less to pursue a case there. An almost equally obvious component is the claim that German litigation is quicker. Delays generally add directly to the monetary costs of litigation, and they increase the indirect and nonmonetary costs by prolonging the participants' uncertainty and anxiety. On both these scores, Langbein's argument for German superiority is convincing: the process of obtaining justice is less expensive there than here.

But what about the value of the outcomes that this process produces? Delay is a factor in this calculation as well: other things being equal, a quick judgment is generally worth more than a slow one. In some types of cases the timeliness of a judgment is the major determinant of its value because the central issue is the legal propriety of a status that has a fixed term - child custody cases, for example, or

practice, however, economists often use a looser definition of efficiency, as I will do here. When a change improves the net productivity of a system, Pareto superiority can sometimes be achieved by transfers; for example, the change I just described would produce a Pareto superior system if the poor person were required to compensate the rich person for his $\$ 1$ loss. Given this possibility, a change is often said to be "efficient" if it makes Pareto superiority possible, if "those who gained by it . . . could compensate those who lost from it and still be better off than before." Calabresi \& Melamed, Property Rules, Liability Rules, and Inalienability: One View of the Cathedral, 85 Harv. L. Rev. 1089, 1094 (1972) (emphasis added); see, e.g., M. PolinSKY, AN INTRODUCTION TO LAW AND ECONOMICS 7 (1983) ("The attractiveness of efficiency as a goal is that, under some circumstances . . . , everyone can be made better off if society is organized in an efficient manner.") (emphasis added). 
appeals by imprisoned defendants - and even when that is not true, justice delayed is justice discounted. Here again, the German advantage is convincing.

The main measure of the social value of a judgment, however, is not speed but accuracy. ${ }^{21}$ A tardy judgment is worth less than a swift one if it is correct, but an erroneous judgment has no value at all, or, more likely, negative value. Hence the efficiency of a system of adjudication is severely undermined to the extent that it produces avoidable errors. Langbein believes that the German system is more likely than ours to reach factually correct results. While this is a plausible consequence of his description of the superior rationality of German procedure, I am unconvinced. I do not think there is enough evidence for a useful comparison, for two reasons: First, while the cost and duration of a legal proceeding are (at least in principle) directly observable, its accuracy is almost always unknown since we rarely have any external evidence by which to judge it. There are some experimental studies that attempt to compare adversarial and nonadversarial adjudication of simulated cases (where the "facts" are created by, and therefore known to, the researchers), but these studies are not very helpful.22

21. See generally R. Posner, Economic ANAlysis of LAw 517-21 (3d ed. 1986).

22. The main work on this issue, done by Professors John Thibaut and Laurens Walker and their associates, is summarized in J. Thibaut \& L. Walker: Procedural Justice, A PsYCHological ANALYsis (1975); see also Lind, Thibaut \& Walker, Discovery and Presentation of Evidence in Adversary and Nonadversary Proceedings, 71 MiCH. L. REV. 1129 (1973); Thibaut, Walker \& Lind, Adversary Presentation and Bias in Legal Decisionmaking, 86 HARV. L. REV. 386 (1972). In the relevant portion of their research, Thibaut and Walker asked experimental subjects to act various roles in a simulated case - in particular the roles of advocate and factfinder - and varied the procedural rules under which the case was processed. They found: (1) When faced with disadvantageous facts, the "lawyers" in the "adversary" procedure invested more experimental resources in "investigating" than those in the "nonadversary" procedure. J. THIBAUT \& L. WALKER, supra, at 28-40. (2) "Adversary" presentation of argument was more likely than "nonadversary" argument to counteract a bias about the outcome that was deliberately implanted in the "judges." Id. at 41-53. Thibaut and Walker's research has been faulted on the ground that it does not adequately reproduce the structure of adversarial and nonadversarial litigation, see Damaška, Presentation of Evidence and Factfinding Precision, 123 U. PA. L. REV. $1083,1095-100$ (1975), but that is not my main criticism. Simulation studies can provide useful information on legal procedures, and they can be informative even when they do not precisely mimic actual practice, if the researchers observe and respect the main elements of the process under investigation. Thus, for example, simulations using naive subjects - college students and subjects from the general population - may be appropriate for studies of jury decisionmaking, because juries are composed of inexperienced, untrained lay people. See, e.g., R. HASTIE, S. PenRod \& N. PEnNINGTon, INSIDE THE JURY (1983). But it is pointless to use college students and first-year law students to simulate the roles of judges and lawyers in adversary and investigatory systems of litigation; even if these subjects develop the appropriate motivation for their roles, they cannot possibly have the essential training. As a result Thibaut and Walker's findings, even accepted at face value, tell us little if anything about the actual operation of American and continental procedures. Trained American lawyers are undoubtedly better at building partisan cases for their clients than Thibaut and Walker's subjects, and trained German judges are probably better at searching for facts and counteracting their own biases. Each system justifies itself in large measure on the basis of the performance of professionals who are experienced and skilled in these roles, and neither can be judged on the basis of studies that fail to take that into account. 
Second, the important question is not how these two fact-finding systems might perform in the abstract, but how many errors they produce in practice. In practice, however, most cases are not litigated. As a result the answer to the question depends in part on the composition of the set of cases that are presented for adjudication, and in part on the resolution of those that are not. This makes cross-national comparisons extraordinarily difficult. In the civil context it would be necessary to consider: (1) the effect of each system of adjudication on the composition of that small subset of disputes that are channeled to litigation in each country, and (2) the "accuracy" of the dispositions of those disputes that are not pursued at all, or settled short of litigation. In the criminal context it would be necessary to compare the error rate (false convictions and false acquittals) of a system based primarily on plea bargaining, to that of a system based exclusively on investigatory fact-finding. The data for these comparisons do not exist and would be exceedingly difficult (perhaps impossible) to gather, and the systems involved are so complex that I am skeptical of arguments on either side made without data, especially arguments based solely on the nature of the processes of formal adjudication.

But while the accuracy contest may be too murky to call, German litigation does seem to have a related lesser advantage: consistency. As with accuracy, there are no systematic comparative data to support this conclusion, but it follows more directly from the professional and hierarchical nature of the German system: the use of professional judges (rather than hired advocates and ad hoc juries) to gather and to evaluate evidence; the requirement of detailed written judgments; and the wide scope of factual and legal review on appeal.

Consistency is related to accuracy, but they are not synonymous. It is a necessary condition for a high degree of accuracy - if similar cases produce inconsistent judgments they cannot all be right - but it is not a sufficient condition. For example, German courts might be consistently more likely than American courts to make some types of errors, and consistently less likely to make others. Still, other things being equal, consistency in itself can add to the social value of legal judgments in two respects: First, it reduces the uncertainty of present and prospective litigants about the likely outcomes of litigation, thereby reducing the costs associated with uncertainty and increasing the proportion and the consistency of out-of-court settlements. Second, when the issue in dispute is normative rather than factual - the appropriate penalty for a crime, the value of general damages for defamation, etc. - the judgments of the courts may be the only standard for evaluating the legal rights and obligations of the parties. In such 
situations the best description of the correct legal result may be the modal judgment across a large number of cases, and deviations from this mode may be considered errors. A more consistent procedure produces fewer such errors: if the mode defines truth, then variance is error, and the German system has less of it.

\section{Common Defenses of AdVersary Fact-Finding}

The American system of litigation, needless to say, has numerous defenders who present many arguments on its behalf. I will touch on them only briefly, as they are tangential to the issue I wish to discuss. Basically, these arguments fall into two categories: (1) Superior accuracy: Adversarial litigation produces fewer errors, or fewer of the worst sorts of errors, than nonadversarial systems. (2) Intrinsic value: Adversarial litigation has political and social advantages that are independent of its direct effects on litigated cases. Significantly, nobody argues that American justice is cheaper or quicker than German justice, or French, or any other foreign product.

\section{A. Superior Accuracy}

The argument that adversarial fact-finding is more accurate than investigatory fact-finding is advanced in different forms. The most general is the claim that the adversarial method is a superior mode of resolving questions even in nonlegal contexts, and that personal, scientific, and social policy questions are or should be addressed in an adversarial manner. ${ }^{23}$ This argument seems to be based on a vaguely disguised non sequitur. It is true, of course, that important decisions in any context should reflect a fair review of all relevant information, including conflicting points of view, if they exist. It does not follow, however, that a partisan structure should be created to ferret out and emphasize (or create) factual disputes, or that evidence should be presented to a passive decisionmaker by conflicting partisans whose commitment to truth is entirely instrumental. That fact-finding structure is unique to the legal system, and if we are to recommend it to others we ought to base our endorsement on its performance in our own hands.

The more promising arguments for adversarial accuracy are more specific. One is the claim that adversarial investigators will find more evidence because each side will be motivated by self-interest to search for facts that will advance its own cause, especially when the initial

23. See, e.g., Freedman, Judge Frankel's Search for Truth, 123 U. PA. L. REV. 1060, 1060-61 (1975). 
evidence looks unfavorable. ${ }^{24}$ This is plausible, but unproven. ${ }^{25}$ On the other hand, any such tendency would have to compete with the conspicuous evidentiary drawbacks of adversarial fact-finding: the biasing effects of partisan preparation of witnesses and presentation of evidence, and the absence of any systematic mechanism for obtaining and considering evidence that neither party identifies as beneficial to its interests. ${ }^{26}$ No data are available to help us gauge the magnitude of these contrary effects, or the balance between them.

A variant of this argument focuses on the decisionmaking process. When the decisionmaker conducts the investigation, his or her initial impressions may distort its course. The best expression of this claim is a frequently quoted statement by Lon Fuller: "[W] hat starts as a preliminary diagnosis designed to direct the inquiry tends, quickly and imperceptibly, to become a fixed conclusion, as all that confirms the diagnosis makes a strong imprint on the mind, while all that runs counter to it is received with diverted attention."27 Again, we are limited by the absence of evidence. Fuller's statement, however eloquent, is no more than a reasonable hypothesis, and its opposite may be equally likely: that an active, investigatory judge is better able than a passive one to test and to disconfirm his or her initial guesses. Fuller's use of the word "diagnosis" is telling: we expect medical doctors to be deliberately skeptical about their first impressions, and, presumably, the more intelligent and better trained among them do a good job of it. Similarly, I would expect the performance of investigating judges to vary directly with their professional quality - their intelligence, their commitment, and their training. If that is so, the accuracy of investigatory fact-finding depends less on the nature of human psychology than on the success of the social processes of judicial selection, training, and supervision.

Perhaps the strongest argument for the superior accuracy of adversarial litigation focuses on the role of juries in criminal cases. (Juries, of course, are not an inevitable feature of the adversary system many American trials are conducted without them - but jury trials are necessarily adversarial since the common-law jury is the quintes(1984).

24. See, e.g., S. Landsman, The AdVersary System: A Description AND Defense 45

25. Landsman, $i d$. , cites Thibaut \& Walker, whose work (and its limitations) is discussed at note 22 supra.

26. See, e.g., J. FRank, Courts on Trial: MYTH and REality in AMERICAN Justice 80-102 (1949); Frankel, The Search for Truth: An Umpireal View, 123 U. PA. L. REv. 1031, $1032-41$ (1975).

27. Fuller, The Adversary System, in TALKS ON AMERICAN LAw 30, 39-40 (H. Berman ed. 1961) (quoting REPORT OF THE JoINT CONFERENCE ON PRofessional. REsPonsibility 5 (Association of American Law Schools/American Bar Association 1958)). 
sential passive factfinder, entirely dependent on the adversaries to find and produce evidence.) Lord Devlin put the matter succinctly: "Trial by jury is not an instrument of getting at the truth; it is a process designed to make it as sure as possible that no innocent man is convicted." 28 In other words, jury trial is better than other methods of determining criminal guilt or innocence because it more successfully avoids erroneous convictions, the type of errors that society considers most costly. ${ }^{29}$ This too is a plausible argument - judges may have a harder time than juries sticking to the requirement of proof beyond a reasonable doubt, given their professional awareness that the great majority of criminal defendants are in fact guilty - and in this case there is solid empirical evidence to support it. Kalven and Zeisel, in their classic survey of over 3500 American criminal jury trials, found that the trial judges thought the defendants should be acquitted only half as often as the juries did (seventeen percent versus thirty-three percent), ${ }^{30}$ and that at least a portion of this difference was attributable to "the jury's more stringent view of proof beyond a reasonable doubt." 31 These are convincing data, as far as they go. They do not prove that fewer innocent defendants are convicted by juries than by judges - juries may simply convict fewer guilty ones - but they certainly suggest that in a case with questionable evidence the risk of an erroneous conviction is lower before a jury than before a judge, in America. But these data do not help us compare distinct systems of adjudication, as opposed to different procedural choices within a single system. It is entirely possible, for example, that a combination of various features of German criminal procedure - including the use of lay judges - provides as much protection against false convictions as we obtain with jury trials, or more. ${ }^{32}$

\section{B. Intrinsic Value}

Cultural and political arguments for adversarial litigation are le-

28. Lord Devlin, The Criminal Trial and Appeal in England, address delivered at the University of Chicago for the Third Dedicatory Conference (Jan. 1960), quoted in H. KALVEN \& H. Zeisel, The AMERICAN JuRY 190 (1966).

29. Cf. R. POSNER, supra note 21 , at 521 , for an economic analysis of the high valuation of errors that result in convicting innocent criminal defendants.

30. H. Kalven \& H. ZeISEL, supra note 28 , at 58. See more generally id. at 55-63. By contrast, Kalven and Zeisel found that in civil cases judges and juries returned similar proportions of verdicts for plaintiffs and for defendants. Id. at 63-64.

31. Id. at 189.

32. In any event, there is reason to believe that the major guarantee of accuracy in criminal adjudication in either system, and the major protection against erroneous conviction, is the quality of the initial police investigation. See Gross, Loss of Innocence: Eyewitness Identification and Proof of Guilt, 16 J. LEGAL STUD. (forthcoming). 
gion. Perhaps the most common is distrust of government. This argument usually focuses on criminal litigation, and in particular on the role of criminal juries as a protection for the accused, "an inestimable safeguard against the corrupt or overzealous prosecutor and against the compliant, biased, or eccentric judge." ${ }^{33}$ This description has deep historical roots - it evokes images such as the jury acquittal of John Peter Zenger on charges of seditious libel in $1734^{34}$ - and, for those rare cases with political overtones, it may well be true. But the general claim that juries are more likely than judges to favor individuals in opposition to the government is more doubtful; it probably depends on the issue at stake. Juries, for example, may be more sympathetic to drunk driving or tax evasion defendants, but less respectful of a robbery defendant's right not to incriminate himself. Indeed, many of our exclusionary rules of evidence and of criminal procedure reflect a mistrust of the ability and the willingness of juries to apply prodefendant policies. On the other hand, one could argue that the very availability of these exclusionary procedures is a justification for criminal trial juries: jurors can be insulated from suppressed evidence, involuntary confessions, etc., but judges, as a practical matter, cannot.

The adversarial method of litigation is also defended on the ground that it is uniquely respectful of the autonomy of the individual. Again, the common version of this argument applies only to criminal defendants: in an inherently unequal contest, where the government seeks to deprive a citizen of liberty or life, the prosecution is forced to meet the defendant on terms of formal equality and thereby acknowledge the defendant as a "sovereign, separate, sentient" individual. ${ }^{35}$ This seems true, in theory; in practice it is undercut by the ubiquitous practice of trial by plea bargain, a pale reflection of the "adversary trial [between] equals - strength against strength, resource against resource, argument against argument." 36 Charles Fried advances a more comprehensive but idiosyncratic version of this argument: the lawyer is a "special-purpose friend" whose role enhances the autonomy of the client, in civil disputes as well as criminal. ${ }^{37}$ This is an odd and contro-

33. Duncan v. Louisiana, 391 U.S. 145, 156 (1968).

34. See J. Alexander, A Brief Narrative of the Case and Trial of John Peter ZENGER (1963).

35. Babcock, Fair Play: Evidence Favorable to an Accused and Effective Assistance of Counsel, 34 StAN. L. REv. 1133, 1139 (1982); see also M. FrEEDMAN, LAWYERS' ETHICS IN AN ADVERSARY SYSTEM 4-6 (1975).

36. Fortas, The Fifth Amendment: Nemo Tenetur Podere Seipsum, 25 CLEv. B. AssN. J. 91, 98 (1954).

37. Fried, The Lawyer as Friend: The Moral Foundations of the Lawyer-Client Relation, 85 YALE L.J. 1060, 1068-72 (1976). 
versial description of a relationship that is typically subject to more abuse than praise, ${ }^{38}$ but it does capture some of the flavor of the lawyer's role: a professional disputer, who will be loyal to his employer. There are lawyers to fill that role in Germany as well as in America, but our system gives them greater scope, which, I suppose, amplifies whatever intrinsic moral value the role may have.

A separate argument for adversarial litigation turns on the role of the judge. By setting judges above the fray, the adversary system is said to enhance their prestige and autonomy, and to make them more effective as guarantors of individual rights. ${ }^{39}$ This argument has two components. On one hand, American judges do have greater prestige than civil-law judges, especially in civil cases. Both their forum and their role are more dramatic, and they have greater individual authority. ${ }^{40}$ On the other hand, it is not clear that they act with greater autonomy and respond less to political pressures than their continental counterparts. The major determinant of that aspect of judicial behav* ior is not likely to be the fact-finding procedure, but rather the structure of judicial careers. Civil-law judges are selected by merit but hemmed in by the civil service bureaucracies in which they serve; American judges are generally appointed by politicans, and most of those that serve in state courts must also stand for election. Undoubtedly some American judges, in particular some federal judges with life tenure, are less constrained than any German judges (which may or may not be an advantage), but it is not obvious where the overall balance of autonomy lies. It is clear that American judges have a greater range of powers - in particular equitable powers - than any European judges, including English common-law judges; but that reflects legal and political policies quite separate from the form of adjudication.

The last set of arguments that I will mention is addressed to the legitimacy of the process of adjudication. The broad claim is that people in general prefer adversary methods - even citizens of civil-law countries - and that they are more willing to accept the results of an adjudicative process in which they could play a free adversarial role. ${ }^{41}$ There are some experimental data that are cited in support of these assertions. ${ }^{42}$ I have doubts about the value of that research, even on

38. See Simon, The Ideology of Advocacy: Procedural Justice and Professional Ethics, 1978 WIS. L. REv. 29; Luban, The Adversary System Excuse, in THE GoOD LAWYER: LAWYERS' ROLES AND LAWYERS' ETHICS 83 (D. Luban ed. 1984).

39. S. LANDSMAN, supra note 24 , at 50.

40. See, e.g., J. MERryman, The Civil LAW TRADition 130-31 (1969).

41. S. LANDSMAN, supra note 24 , at 45.

42. J. THIBAUT \& L. WALKER, supra note 22 , at $67-80$. 
its own terms, ${ }^{43}$ but my main problem is more basic: it addresses the wrong question, at least for present purposes. At most, the data show that American and European experimental subjects - university students - have an abstract preference for adversarial procedures. But in order to compare reactions to the American and the continental systems in practice we would need to know how American and continental litigants feel about their respective systems, as they actually operate. On that comparison we have no useful information.

A similar but more limited claim focuses, once more, on the jury system. Jury service is said to be a species of direct citizen participation in government that increases both the legitimacy of the government in the eyes of the jurors and the legitimacy of the court's decision in the eyes of the parties and of the community, especially in criminal cases. ${ }^{44}$ This may be so, but it is not self-evident. A jury system that is inherently messy and slow may inspire less confidence in the participants (or in anybody else) than an efficient system with no direct citizen participation; it may even be more disillusioning than an equally inefficient system that is more remote from the citizenry.

Finally, the adversary system is sometimes defended on the ground that it has important symbolic and ceremonial importance. In particular, criminal trials are said to provide a forum for "community catharsis"45 and to be a form of drama that reaffirms social values by serving not only the substance but also "the appearance of justice." 46 To the extent that this is a valuable function, adversary trials may be better structured to serve it than investigatory trials since they are more formal and more dramatic. But comparisons are difficult because, on the whole, the cathartic impact of legal ceremonies is culturally bound and culturally determined. In law as in religion, the ceremonies that affect us most are usually those that are most familiar. ${ }^{47}$

43. Thibaut and Walker presented their subjects with various hearing procedures, but none of them was a fair depiction of the continental investigatory trial, however simplified. In particular, the parties in Thibaut and Walker's "inquisitorial" hearings had no right to a legal representative of any sort, and no role whatever in producing evidence. Id. at 68-70, 78-79.

44. See, e.g., Taylor v. Louisiana, 419 U.S. 522, 530 (1975).

45. Richmond Newspapers, Inc. v. Virginia, 448 U.S. 555, 571 (1980).

46. Richmond Newspapers, 448 U.S. at 571-72; see Babcock, supra note 35, at 1136-41.

47. Some commentators also defend the adversary system on the ground that it is recognized by our Constitution and, perhaps, constitutionally required. See, e.g., S. LANDSMAN, supra note 24 , at $47-48$. There is some truth to this; the jury trial, confrontation, and counsel provisions of the sixth amendment seem to presuppose common-law criminal trials, and the seventh amendment seems to presuppose common-law civil trials and specifically requires common-law restrictions on civil appeals. In addition, the due process clauses of the fifth and fourteenth amendments have frequently been interpreted to require common-law type adversary proceedings (although the extreme claim by some scholars that "due process" means adversariness, see, 


\section{Summary}

Some partisans of adversarial fact-finding claim that it is more accurate than investigatory fact-finding, but - except for the possibility that criminal juries are less likely than common-law judges to convict innocent defendants - this claim is unproven and not inherently persuasive. Most defenders of adversarial litigation, however, argue that its primary virtues are effects other than superior accuracy, ${ }^{48}$ and most of the claimed benefits they point to are peculiar to criminal litigation. In terms of efficiency, these two categories of arguments make two separate points: (1) Adversarial litigation is more efficient than investigatory litigation, despite its higher process costs, because it produces a more valuable output, i.e., a more accurate set of decisions. (2) The inefficiency of the adversarial system is an incidental cost of implementing social and political goals apart from the actual conduct or outcomes of litigation. The argument in the section that follows is different: that efficiency in litigation may be intrinsically worrisome, and inefficiency intrinsically attractive.

\section{The AdVANTAges of INEFFICIENCY}

\section{A. Some Drawbacks of Efficient Systems}

The major method of increasing efficiency in a labor-intensive activity - and law is certainly that - is specialization. This basic truth has been recognized at least since the time of Adam Smith, ${ }^{49}$ along with its inevitable consequence: efficiency, in this context, implies complexity. Complexity, of course, is not efficient in itself - unnecessary complexity is inefficient - but there is an unavoidable increase in necessary complexity as a system of operation becomes more efficient. Since specialization increases the number of distinct roles that are involved in a process, it requires a more elaborate structure for choosing and training people to fill these roles, and a more complex set of relationships among them. For similar reasons, efficiency implies concentration or centralization of social tasks. As with complexity,

e.g., Freedman, supra note 23, at 1061, is clearly an overstatement). But this judicial interpretation of due process is explicitly described as a consequence of the universal American reliance on common-law methods of adjudication. In that context, due process requires jury trials, adversarial cross examination, etc.; in other procedural settings, it might not. Duncan v. Louisiana, 391 U.S. 145, 149 n.14 (1968). It is ironic that these holdings are cited as justifications for the system they assume. In any event, whatever the legal theory, the constitutional status of the adversary system is ultimately not a separate argument for that method of litigation but a description of some aspects of its history and its legal status.

48. See, e.g., S. LANDSMAN, supra note 24, at 3, 44-51; Freedman, supra note 23, at 1065.

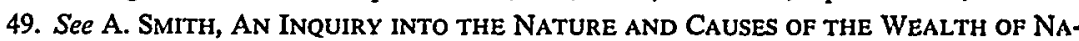
Tions (R. Campbell, A. Skinner \& W. Todd eds. 1976) (1st ed. 1776). 
centralization can be inefficient, but some degree of centralization is an inherent consequence of specialization: when each actor is trained for a single role, each task can only be performed by that small set of actors who have been assigned to the appropriate role and who have received the proper training.

The comparison between German and American litigation provides a good example of this general pattern. In America, the responsibility for investigating and presenting evidence is diffused among an army of relatively unspecialized private litigators; in Germany, it is concentrated in a specialized cadre of state functionaries. The American system focuses heavily on a single role, that of the advocate. Litigation is dominated by advocates, and judges are drawn directly from their ranks with no significant additional training. American practice also minimizes distinctions among advocates. The roles of prosecutor and criminal defense attorney are more similar than in civil-law countries (indeed, the same lawyers often move from one side of that line to the other), private practitioners frequently handle both civil and criminal trials, and there is little specialized training for any of these tasks. The German system also requires advocates for the parties (as Langbein emphasizes), but in addition it includes another role with no American parallel, the investigating judge. This is a separate job with separate training and no overlap in personnel. In German criminal cases the roles of the advocates are also more differentiated than our own. The German prosecutor is primarily an investigating official, with an explicit duty to search for evidence for both sides, and with little of the power and autonomy we generally associate with the legal representative of a party. As with judges, German prosecutors follow a specialized career line wholly apart from private practice. ${ }^{50}$ Finally, the German system incorporates a much broader right of appeal than ours, which is only possible because German appellate judges (unlike our own) specialize in the cases they handle. ${ }^{51}$

There is nothing wrong with a complex apparatus or with a centralized structure, when they work; quite the contrary. As we all have learned, word processors have enormous advantages over typewriters and centralized computers may be even better, when they are operating properly. Unfortunately (as many of us have also learned) they are also considerably harder to set up and to use, and unless you can operate a word processor or a computer reliably, a typewriter will serve you better. The German system of litigation depends on a core ele-

50. Langbein, supra note 2, at 211.

51. See generally Meador, supra note 9. 
ment that is considerably trickier than a microchip: an efficient judicial bureaucracy, with high standards for training and performance. In criminal cases, German fact-finding also depends on the integrity and the competence of German prosecutors, the creatures of another state bureaucracy. The Germans appear to have developed efficient judicial and prosecutorial bureaucracies, but that fact tells us little about the risks of trying: we could try and fail. This is not merely an abstract worry. Germany is not the only country with a civil-law system of adjudication, but it is one of the most successful. Italy, for example, is sometimes said to have a peculiarly inefficient legal system, despite (or perhaps because of) its nonadversarial structure: "The Italian legal system is like the German, except that it doesn't work."52

A specialized social system is not only more difficult to construct than a less efficient one, it also demands more of its social environment. Since specialization implies concentration and centralization, it reduces the flexibility and adaptability of an organization; and because specialization entails complexity, it increases the number of elements that are essential to the operation of a social apparatus and multiplies the number of factors that can interfere with it. I do not mean to imply that any specific combination of social and political features is necessary as the setting for a legal system of the German type, and certainly not that the German system of litigation requires German culture. That could be true, but it seems more likely that with sufficient ingenuity, modified versions of the German system could be made to fit many different social contexts - but only one at a time. Any particular solution would be tied to the setting it was designed to fit, and would be, by comparison with more primitive and less efficient systems, intolerant of diversity and of change. A biological analogy may be appropriate. The more widespread organisms are not as a rule those specialized ones that most efficiently exploit the resources of any particular environment, but rather less efficient species that can tolerate diverse environments. In periods of rapid environmental change these inefficient organisms are more likely to survive and to evolve and adapt to the new conditions than their more efficient contemporaries. ${ }^{53}$

This limitation of specialized systems poses a problem for any attempt to import the German legal system to America. However diffcult it might be to construct and to operate an efficient and honest state bureaucracy of investigating judges and a parallel bureaucracy of civil-law prosecutors in a relatively homogeneous European society,

52. Oral communication from J. Langbein (quoting Professor Mauro Cappellitti).

53. See, e.g., 2 K. LORENZ, STUdiES IN ANIMAL AND HUMAN BEHAVIoR 173-78 (R. Martin trans. 1971). 
the problem in America is considerably worse. Social diversity in America is extreme. This is a very large country; we are still in part a nation of immigrants; our population includes a half dozen major racial and ethnic minorities and is becoming, if anything, more diverse; 54 and our traditions of individualism and mobility have produced a society of unparalleled cultural heterogeneity. In addition, the American political system is extraordinarily fragmented. We have numerous separate (and, in the case of states, sovereign) political entities; in most of these entities political power is divided between competing legislative and executive authorities. Our political parties have little power at the national level - and progressively less at lower levels - to discipline these diverse forces. It is possible that judicial and prosecutorial bureaucracies of the German type could be established in America, or in some large portion of it, and it is conceivable that they could acquire the competence, the legitimacy, and the respect that they would need to operate effectively. But the situational obstacles are formidable.

The fact that a civil-law system of litigation might work poorly in America is not, in itself, a sufficient basis to disfavor that system. We must also ask: "Compared to what?" Langbein argues that our common-law system already operates quite poorly: it produces inefficient and uneven justice. Could a switch make matters worse? I think so. Complex and centralized systems are not only harder to set up and more likely to break down, but they break down more thoroughly. When a central component of a complex apparatus malfunctions, everything stops, and the failure typically requires drastic repairs. Specifically, a bad civil-law system would be worse than anything the common law can produce. Incompetent or dishonest judges and investigating prosecutors would be slower, less consistent, and less accurate than any changing cast of private advocates and lay jurors, and entrenched bureaucracies are notoriously hard to displace. Langbein recognizes this problem, and admits that if put to the choice he might prefer the American procedure to the risk of placing a lawsuit in the hands of some of the less attractive judges of his home jurisdiction, Cook County, Illinois. 55 Langbein attributes his wariness to the American institution of judicial selection by politicians (a ripe candidate for criticism), and more generally to the absence of selection and promotion by merit. Political cronyism, however, is merely the pathology that happens to be common here and now. The civil-law sys-

54. Bureau of the Census, U.S. Dept. of Commerce, Statistical Abstract of the UNITED STATES 1985, at 35, 86-89 (105th ed. 1984).

55. Langbein, supra note 1 , at 853-54. 
tem of adjudication could also be undermined by other common bureaucratic problems, such as complacency, inflexibility, inaccessibility, or bias. Its vulnerability to problems of this type is an intrinsic aspect of centralization and specialization, the same factors that make it potentially so efficient.

In short, the superior efficiency of the German system of adjudication is a product of specialization, which makes the system more complex and centralized. As a result, it is inherently more difficult to set up and to operate than the common-law system, less adaptable, more fragile, and, once broken, harder to fix - in other words, a bad risk.

\section{B. Some Benefits of Inefficient Adjudication}

The risk that a more efficient system of litigation will fail is an instrumental argument against plans to use such a system. But there is a more fundamental argument - that inefficient systems are not only more robust, but that their inefficiency is beneficial in itself. This argument has several strands.

One parochial advantage of inefficiency concerns the peculiar position of judges in America. As I have noted, the passivity of American judges is sometimes said to fortify their role as guarantors of individual rights in opposition to the government. ${ }^{56}$ The inefficiency of the judicial apparatus has a parallel function. The German judge operates the judicial machinery of his system. The American judge presides over his dominion; he has less control but more prestige and authority. $\mathrm{He}$ also has a wider range of powers and roles than his German counterpart, including uniquely American opportunities to act on matters of public policy. To the extent that this judicial policy-making role is valuable - and we seem to value it - an inefficient judicial system may be a necessity. It would be difficult to justify, or tolerate, allocating that sort of political power to judicial officials if they had the means to implement their policies directly and effectively.

The most basic effect of inefficiency in a system of adjudication is that it deters litigation. A person who agrees with Learned Hand that "as a litigant, I should dread a lawsuit beyond almost anything else short of sickness and of death," 57 will do a lot to avoid the courts. Our inefficient system fosters this belief; indeed, this effect is one of the chief complaints against our legal system. But it has advantages as well, the most obvious of which is the conservation of resources fewer court cases cost less to handle. Conceivably, one could argue

56. See text at note 39 supra.

57. Quoted in J. FRANK, supra note 26, at 40. 
against increasing the efficiency of courts on the ground that it would produce an expensive flood of litigation, but this is not a telling argument. For one thing, most of the new cases that would be susceptible to litigation would not actually go to court, but would be disposed of by negotiation in the enlarged shadow of the law. In addition, a more efficient system could save as much public money or more (at least in civil cases) without discouraging litigation, by reducing overall costs while simultaneously requiring the litigants to bear more of the expense of the public aspect of the process. Other advantages of discouraging litigation, however, are not so illusory.

The more substantial benefits of procedural inefficiency have to do with its effects on conduct outside of court. Every legal system leaves some "zone of immunity"58 around individuals, a sphere of actions that because of their nature or magnitude are not as a practical matter subject to government control. We all know, for example, that despite specific legal obligations to the contrary we can drive our cars on expressways at sixty or sixty-five miles per hour, or pay our bills a month late, and, except in extraordinary circumstances, we will not be prosecuted or sued. The size of this zone varies considerably from one culture to another. In China, from what $I$ hear, it is quite small; 59 in America, it is relatively large. A major consequence of inefficiency in the legal system is to increase the range of conduct that is, as a practical matter, beyond formal legal control: as litigation becomes slower, more expensive, and less predictable, a larger class of cases will not be brought because they are not worth the cost, the trouble, or the risk.

Making the courtroom unavailable to a whole class of cases does not seem, at first blush, to be a procedural virtue; on the contrary, it is often cited as an essential vice of our system. But it has benefits as well. Coercive state intervention in private conduct is an extreme and disruptive cure; if the problem is minor, it may be worse than the illness. Making legal medicine expensive and unpalatable reduces the danger that it will be overused. The value of this deterrent function is a direct function of the value we place on individual autonomy and privacy - which in our society are highly regarded.

Every interpersonal dispute starts with a grievance by some person or group against another, or with several such grievances. One effect of legal inefficiency is to choke many potential disputes at that stage, to prevent them from ever being addressed. But inefficiency also affects the resolution of those grievances that do mature into disputes,

58. Cf. L. Friedman, Total Justice 22, 8488 (1985).

59. See, e.g., V. LI, LAW WITHOUT LAWYERs: A COMPaRATIVE VIEW OF LAW IN CHINA AND THE UNITED STATES 38-47 (1977). 
and, again, those effects that are commonly recognized are roundly condemned. The most telling criticisms are those that focus on the largest category of disputes, those that are settled short of court. The costs of inefficiency are not evenly distributed; in the context of bargaining, expense and unpredictability are extra-legal advantages to the stronger and larger party (because it can better afford the costs and the risks), and delay is an extra-legal advantage to the party on the defense (because it retains the benefits of the status quo during the pendency of the case). The parties that have these positional advantages can and do use them to exact concessions in negotiated settlements. ${ }^{60}$

But inefficiency in litigation has other consequences for negotiated settlements as well. First, the diversity of outcomes of an inefficient process of litigation may promote diversity in the outcomes of private bargaining. Second, and more important, to the extent that the formal legal system is inefficient it becomes increasingly irrelevant to the negotiated resolution of disputes. Thus, for example, in $\mathrm{H}$. Laurence Ross' classic study of out-of-court settlements of automobile accident claims, he found that insurance adjusters divided their work load into two distinct categories: a small set of "big cases" that could conceivably go to trial, and a much greater number of "small cases," for which the court costs would be disproportionate to any possible award.61 Claims in the few big cases were evaluated and settled primarily by reference to their "jury value," the adjusters' estimates of the sums that they might bring in court, but for the multitude of small cases predicting a jury's verdict was both impossible and irrelevant. Such cases almost never went to trial, and if they had, the verdict would have been only a fraction of the insurer's costs. As a result, settlements in small cases were guided by a completely separate system of valuation. Similarly Robert Ellickson found, in his study of cattletrespass disputes in Shasta County, California, that because of the high cost of the legal system landowners resolved their problems without reference to it - "beyond the shadow of the law" - using a set of norms that had no systematic relationship to their legal entitlements. ${ }^{62}$

In other words, inefficiency limits the effectiveness, the "penetration" of formal legal rules, and creates room for divergent results and for patterns of behavior based on nonlegal norms. This is not an obvious advantage. It runs counter to the central ideological premise of

60. See, eg., Cooter, Marks \& Mnookin, Bargaining in the Shadow of the Law: A Testable Model of Strategic Behavior, 11 J. LEGAL STUD. 225 (1982).

61. H.L. Ross, SETTLED OUT OF COURT 106-13 (1970).

62. Ellickson, Of Coase and Cattle: Dispute Resolution Among Neighbors in Shasta County, 38 STAN. L. REV. 623, 628-29, 672-73 (1986). 
the rational-legal mode of authority: that social behavior is best regulated by explicit rules that are formally enacted and impersonally implemented. ${ }^{63}$ In practice, however, this ideology performs unevenly; for one thing, we often enact bad laws. Fortunately, however, we are sometimes spared the worst consequences of our foolishness by our failure to implement it effectively. Prohibition in twentieth-century America is a conspicuous example: however bad it was in fact, it would have been far worse if it had been well enforced. In that case, it is likely that effective enforcement was simply impossible under any procedural system, but in less extreme situations our inefficiency has saved us from the harm we could have accomplished with a more potent judicial apparatus. For example, a recurring feature of recent American politics is the enactment of absurdly draconian criminal statutes, such as the "Rockefeller drug laws" in New York, which (among other things) made the sale of an ounce of heroin punishable by life imprisonment. ${ }^{64}$ Happily, as often as not these laws are beached on the sands of delay and compromised by the tides of plea bargaining. 65

In theory, the value of inefficiency as a brake on political folly is not intrinsic. Perhaps if we had a more powerful engine we would learn the discipline to operate it safely; but perhaps not. In the short run, at least, there would be serious risks. By comparison to other Western democracies, American politics is conspicuously undisciplined and unstructured; this may be one reason we tolerate - if not depend upon - the large political role we have assigned to judges, who operate on the whole outside the usual political machinery. By the same token, we may have come to depend upon the inefficiency with which we translate political policy into legal practice.

The essential impact of inefficiency, however, is not that it limits the reach of bad laws but that it limits the reach of any laws. If legal inefficiency has intrinsic value, it must be because that inevitable effect is valuable - and it may be. Some of the benefits have already been mentioned, in particular the enhanced scope of privacy. But there are also advantages for those activities that remain subject to social control. First, the diversity that is produced by inefficiency - diversity in private settlements and arrangements as well as diversity in adjudi-

63. See M. Weber, The Theory of Social and Economic Organization 324-41 (A. Henderson \& T. Parsons trans. 1947).

64. Act approved May 8, 1973, ch. 276, $\S \S 6(1), 9(2)(a), 19,1973$ N.Y. Laws 1040, 1043, 1044-45, 1053-54 (amended 1979).

65. See, e.g., Joint Committee on New York Drug Law Evaluation, The Nation's Toughest Drug Law: Evaluating the New York Experience 100-15 (1977). 
cated outcomes - may be socially valuable, at least in a society that prizes individualism and change. Second, and more important, the rules that govern disputes that are settled without reference to the legal system may be superior to the legal rules they replace. For example, after reading Ross' excellent book, it is hard not to conclude that the rough-and-ready extra-legal rules for settling "small" automobile accident cases are better than the process of evaluating the "legal" value of "large" cases. ${ }^{66}$ Similarly, Ellickson implies that the informal norms that actually govern cattle disputes in Shasta County are more sensible than the legal rules that apply in theory. ${ }^{67}$

But why not simply rewrite the legal rules to incorporate the advantages of these informal methods? When it is possible, this can be the method for successful reforms: to bring formal rules into line with developing operational norms. Often, however, it cannot be done. Informal norms of behavior suffer from the limitations of their advantages: their relative flexibility, and their responsiveness to interests that legal systems are hard pressed to regulate - trust, reputation, civility, etc. Because of these features, such norms may operate very well in practice, and yet be too vague, too complex, too changeable, or too personal to enact as laws, or even fully to articulate. Nor would it help for the legal system to opt out of an area of behavior entirely and give informal norms free rein: a coercive option, but one that is rarely used, is necessary as a boundary, to keep the normative system intact. A separate but inefficient system of legal rules may strike just the right balance.

\section{CONCLUSION}

As I said at the outset, I am not wedded to the argument that efficiency in litigation is risky or harmful, or that inefficiency is beneficial. Some of the opposite arguments (which I have not made here) are at least equally powerful: under some conditions, inefficient systems may be more likely to fail than efficient ones; inefficient litigation imposes heavy costs on litigants and on potential litigants; good laws as well as bad ones may be undermined by judicial inefficiency. My point rather is that efficiency is a questionable standard for evaluating a system of adjudication one way or the other. The requirements and

66. H.L. Ross, supra note 61. For example, while the valuation of damages in small cases depended primarily on objective factors, in particular medical expenses, $i d$. at 106-11, the assessment of the "jury value" of large cases was more variable and refiected in part such factors as "the sympathetic or antipathetic characteristics of the parties," their "[a]ge, race, sex and occupation," the "reputed skill of the attorneys," and "the nature of the court in which the case might be brought." Id. at 113 .

67. Ellickson, supra note 62 , at $686-87$. 
the effects of such a system are inevitably too complicated to be captured by so elegant and economical a measure.

Efficiency is a seductive concept. Its objective - maximum value per cost - is undeniably attractive, and it is a powerful measure of performance in any context that is sufficiently well defined that the benefits and the burdens are both understood. But when the issue is the procedural structure of a legal system, those conditions are not met. Is the legal system best understood as a hospital, to which patients resort to be treated for legal illnesses? If so, few would question efficiency as a guiding value, although some might caution against risking a disruption in an attempt to improve it. But the legal system might also be viewed in part as a cultural institution, perhaps a critical one - as a school, or a library, or a theater. Under this view, efficiency is a troublesome measure: useful in part, irrelevant in part, and potentially stifling and destructive. Or is the legal system a coercive apparatus - a police force, perhaps even a secret police? If so, we might want affirmatively to limit its efficiency. All of these metaphors are available, and others; the value one attaches to legal efficiency may simply depend on which of them seem most attractive. 